\title{
Customer Experience Management (Cem) In Selected Private Banks in Chennai City
}

\author{
Jaya Krishna V, TR. Kalai Lakshmi
}

\begin{abstract}
The Customer Experience Management (CEM) becomes essential component in any kind of business. The customers of private bank interact with the banks through various touch points such as branches, ATMs, E-corner, Internet banking, etc. The main objective of the study is to explore the customer experience management in selected private banks in Chennai city. The researcher gathered the primary data through structured interview schedule from the first three private banks (i.e. HDFC, ICICI, and Axis bank). The sample size of the research is 150. The findings of the study explored that "Mechanic Clues" is the most important factor that improves the Customer Experience Management in the selected private banks followed by Functional Clues and Humanic clues.
\end{abstract}

Keywords: Functional clues, Mechanic clues, Humanic clues, Customer Experience Management, private banks.

\section{INTRODUCTION}

The customers are the Kings of any business. The satisfaction of customer needs and wants through appropriate products and services are the core element of any business process. The Banking industry is also not an exception to this paradigm. The hyper competition in the banking industry due to mushrooming of private banks in India demands not just customer satisfaction, rather than delighting the customers which means offering products and services more than customer expectations. The customer experience management is a very important concept which deals with satisfaction of customers at all touch points of the private banks. The banks provide its products \& services through various touch points such as branches, ATMs, E-Corners, Internet banking, etc. It's also the known fact that the customers' expectations are changing very rapidly according to the technological changes around the globe. Hence, it's the need of the hour to explore the customer experience management at private banks in Chennai city.

\section{LITERATURE REVIEW}

Prashant Chauhan and Samar Sarabhai (2018), examined the development of CEM and presented a conceptual framework for CEM. The marketing domain has transformed to a greater extent in last two decades. The thrust has moved towards

Revised Manuscript Received on July 22, 2019.

Jaya Krishna V, Research Scholar, School of Management Studies, Sathyabama Institute of Science and Technology, Chennai, E.Mail. jk.cs13@gmail.com

Dr.TR. Kalai Lakshmi, Research Guide, School of Management Studies, Sathyabama Institute of Science and Technology, Chennai. Email kalailakshmi.soma@sathyabama.ac.in. customer centric approach. The role of customer has advance as an enabler to ensure the success of a product/brand.

Ruth et al. (2018) explored innovations in customer experience at the intersection of the digital, physical and social realms. The conceptual framework identifies eight "dualities," or specific challenges connected with integrating digital, physical and social realms that challenge organizations to create superior customer experiences in both business-to-business and business-to-consumer markets. This paper provided guidance for managers in designing and managing customer experiences that the authors believe will need to be addressed by the year 2050. This paper discusses important societal issues, such as individual and societal needs for privacy, security and transparency.

Suvarchala and Narasimha Rao (2018), in their paper attempted to trace out the elements of CEM and the various factors leading to the neglect of CEM in banking sector. The competition among the organizations in financial services sector is continuously increasing. Banking industry is a backbone of nation's economy and it is one of the largest industries in India in terms of revenue and employment. Customer experience is the product of an interaction between an organisation and a customer over the duration of their relationship. The key elements like strategy, culture, processes and systems etc. impact the CEM in banks.

Suvarchala and Narasimha Rao (2018) examined the perception of customers of State Bank of India and HDFC Bank while availing the services. CEM is the process that companies use to oversee and track all connections with a customer. Organizations are using CEM approach to expect customer needs and adopt the mind-set of the customer. The main aim of CEM is to enhance the customer experience through the loyalty of the customers in a multi-channel business environment with complete satisfaction.

Khusnul Khotimah and Nur Choirul (2016), examined the concept of Customer Experience at both companies manufacture and services, as well as provide ongoing attention at each research programme is recommended. Term paper writing method used is the study of the literature on the concept of scientific journals, case studies, and research results related to Customer Experience theory developed by experts from a variety of literature (journal). Implications of papers is expected to further develop the model measuring customer experience so that it can be found a concept or theory that fit, for any problem concerning increase business customer experience measurement and customer experience. A conceptual model of marketing focus developed is a model strategy for the market (market strategy) by focusing on the customer experience analysis

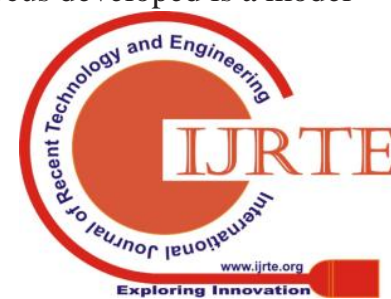




\section{Customer Experience Management (Cem) In Selected Private Banks in Chennai City}

entitled customer experience Model (Theory of Customer Experience).

\section{THEORETICAL FRAMEWORK OF CUSTOMER EXPERIENCE}

According to the Oxford English dictionary, the term experience is defined as the "actual observation or practical acquaintance with facts or events". According to consumer behavior research "an experience is totally all about personal happening, often with significant emotional importance, initiated on the interface with motivations which are the services or products consumed by the customer".

Customer experience is the totality of all the customer's interfaces with a bank at various touch points, over time. In other words, customer experience is the gain of value to the customer from the specific touch point i.e., some touch points may be more important in the experience while compared to others. Therefore, it's an important to look at the bank's own business practices comprehensively through the eyes of their customers to understand how they measure up to their customers' needs and expectations. Conducting customer-satisfaction surveys is not enough. To better serve the customer base and more effectively acquire new customers, the private banks need to delve into the details of individual interactions to understand the relationship between each customer touch point and the value it delivers to customers. Value may be built through a series of positive experiences, but it is maintained through consistently meeting the needs and expectations of their customers throughout the customer lifecycle.

According to service marketing, the service become factual when a customer interacts with some specific prerequisites such as bank, activities, people, and the channel through which they interact with the bank (Mascarenhas et al., 2006). Customer Experience Management

(CEM) through analysis of touchpoints help to uncover powerful customer insights as well as opportunities to improve how well you meet customer-segment needs and wants. Systematically evaluating performance across all customer touch points can lead to better organizational alignment; increased brand perception; and concrete improvements in acquisition, retention, and up-sell and cross-sell efforts.

\section{Functional Clues}

Functional clues are concerned with the technical quality if the service offerings, especially the reliability and competence of the actual service. It includes the service quality, the ease of use, fees and rate of interest offered by the bank to their customers. It is fundamental for the service experience that businesses evaluate and manage the functional clues of their service offerings effectively to meet customer's expectations (Berry et al., 2006).

\section{Mechanic Clues}

The term 'Mechanic clues' are derived from tangible non-living objects and offer a physical representation of the service. According to World banking report, Capgemini (2011), Mechanic clues includes branch layout, ATM design

and environment of the surroundings, bank's website, lighting and other sensory clues visualize the service, communication with customers without words. In simple words, mechanistic clues include "the environment in which the services is accumulated and in which seller and consumer act together, shared with physical commodities that enhance the performance of the service (Booms and Binter, 1981).

\section{Humanic Clues}

Humanic clues includes the actions and appearance of employees and the service providers. For example, the words, tone, level of enthusiasm, dress code, and body language during interaction with the customer (Berry et al., 2006).

\section{RESEARCH METHODOLOGY}

The research design followed in the present research is descriptive research design which describes the customers' perception towards customer experience management at various touch points of retail banking segment of selected private banks in Chennai city

TABLE 1. LIST OF WORLD'S BEST BANK 2019

\begin{tabular}{|c|l|l|}
\hline $\begin{array}{c}\text { S. } \\
\text { No }\end{array}$ & Name of the Bank & \multicolumn{1}{|c|}{$\begin{array}{c}\text { Head } \\
\text { Quarters }\end{array}$} \\
\hline $\mathbf{1}$ & HDFC Bank & Mumbai \\
\hline $\mathbf{2}$ & ICICI Bank & Mumbai \\
\hline $\mathbf{3}$ & Axis Bank & Mumbai \\
\hline 4 & Vijaya Bank & Bengaluru \\
\hline 5 & Allahabad Bank & Kolkata \\
\hline 6 & Punjab National Bank & New Delhi \\
\hline 7 & Syndicate Bank & Bengaluru \\
\hline 8 & IDFC Bank & Chennai \\
\hline 9 & Kotak Mahindra Bank & Mumbai \\
\hline 10 & DBS Bank & Singapore \\
\hline
\end{tabular}

(Source: Forbes and Statista- The World's Best Banks 2019)

The table 1 presents the list of 'The World's Best Banks 2019' released by Forbes in association with market research company Statista. Among the ten companies listed in the above table nine are headquartered in India, whereas the DBS bank is head quartered in Singapore. The researcher gathered the primary data through structured interview schedule from the first three private banks (i.e. HDFC, ICICI, and Axis bank) mentioned in the above table. The researcher used customer experience management scale developed by Berry et al., (2006). The sample size of the research is 150 and 50 samples were collected from each bank from various branches of Chennai city. The pilot study was conducted among 30 samples (10 samples from each bank) from all the three banks, and the reliability of the schedule was determined and tabulated in table 2 . 
Table 2. Reliability Coefficients

\begin{tabular}{|c|l|c|c|}
\hline S. No & Factors & $\begin{array}{c}\text { No. } \\
\text { of } \\
\text { Item } \\
\text { S }\end{array}$ & $\begin{array}{c}\text { Cronbac } \\
\text { h Alpha }\end{array}$ \\
\hline 1 & Functional & 5 & 0.801 \\
\hline 2 & $\begin{array}{l}\text { Mechanic } \\
\text { Clues }\end{array}$ & 5 & 0.783 \\
\hline 3 & Humanic Clues & 5 & 0.904 \\
\hline
\end{tabular}

From table 2, it is recognized that the Cronbach alpha coefficients of the factors used in the research are more than 0.7 which indicates that all these factors are reliable and fit for the research.

\section{V.RESULTS AND DISCUSSION}

The demographic profile of the sampled customers is described in the table 3.

TABLE 3. PROFILE OF THE SAMPLED CUSTOMERS

\begin{tabular}{|c|c|c|c|}
\hline $\begin{array}{l}\text { S. } \\
\text { No }\end{array}$ & Particulars & $\begin{array}{c}\text { No. of } \\
\text { Responde } \\
\text { nts }\end{array}$ & Percent \\
\hline 1 & Gender & & \\
\hline & Male & 94 & $62.67 \%$ \\
\hline & Female & 56 & $37.33 \%$ \\
\hline 2 & Age category & & \\
\hline & Up to 25 Years & 34 & $22.67 \%$ \\
\hline & 26- 50 Years & 88 & $58.67 \%$ \\
\hline & Above 50 Years & 28 & $18.66 \%$ \\
\hline 3 & Qualification & & \\
\hline & Undergraduate & 69 & $46.00 \%$ \\
\hline & Post-graduate & 47 & $31.33 \%$ \\
\hline & Others & 34 & $22.67 \%$ \\
\hline 4 & $\begin{array}{l}\text { Association with } \\
\text { No. of banks }\end{array}$ & & \\
\hline & Only one & 24 & $16.00 \%$ \\
\hline & Two Banks & 84 & $56.00 \%$ \\
\hline & $\begin{array}{l}\text { More than two } \\
\text { Banks }\end{array}$ & 42 & $28.00 \%$ \\
\hline 5 & $\begin{array}{l}\text { Years of } \\
\text { Association with } \\
\text { the Bank }\end{array}$ & & \\
\hline & $1-5$ Years & 62 & $41.33 \%$ \\
\hline & $5-10$ Years & 53 & $35.33 \%$ \\
\hline & Above 10 Years & 36 & $24.00 \%$ \\
\hline 6 & $\begin{array}{l}\text { Most bank } \\
\text { transactions are }\end{array}$ & & \\
\hline
\end{tabular}

\begin{tabular}{|c|c|c|c|}
\hline & done through & & \\
\hline & $\begin{array}{l}\text { Bank Branch by } \\
\text { in person }\end{array}$ & 38 & $25.33 \%$ \\
\hline & $\begin{array}{l}\text { ATMs and } \\
\text { E-Corners }\end{array}$ & 63 & $42.00 \%$ \\
\hline & Internet Banking & 49 & $32.67 \%$ \\
\hline 7 & $\begin{array}{l}\text { Type of Account } \\
\text { in the present } \\
\text { bank }\end{array}$ & & \\
\hline & Savings Account & 92 & $61.33 \%$ \\
\hline & Current Account & 16 & $10.67 \%$ \\
\hline & Loan Account & 42 & $28.00 \%$ \\
\hline & Total & 150 & 100 \\
\hline
\end{tabular}

- The outcome of the above analysis shows that majority of the sampled customers are male which has accounted to nearly $62.67 \%$ and remaining $37.33 \%$ of the customers are female.

- Majority (58.67\%) of the sampled customers belong to the age group of 26 to 50 years (i.e.) middle age category of customers, $22.67 \%$ of the customers are below the age group of 25 years who belong to the young generation customers and $18.66 \%$ of the customers are aged above 50 years.

- With regards to their academic qualification, $46.00 \%$ of them are undergraduates, $31.33 \%$ of them are postgraduates and about $22.67 \%$ of them fall under the others category such as ITI/ Diploma holders and school level of qualification.

- Majority $(56.00 \%)$ of the customers opined that they have association with two banks for carrying out their banking operations, $28.00 \%$ of the stated that they have association with more than two banks for their banking activities and $16.00 \%$ of the indicated that they are associated with only one bank for carrying out their banking transactions.

- The analysis also point out the number of years of association that the customer have experienced in the banking services, where $41.33 \%$ of them are associated with the banking activity for less than 5 years, while $35.33 \%$ of them have formed an association with the chosen banks for period of 5 to 10 years and nearly $24.00 \%$ of the customers are having more than 10 years.

- With regards to the mode of carrying out the transaction about $42.00 \%$ of them opined that they carry out most of the banking transactions through ATMs and E-Corners, whereas around one-third $(32.67 \%)$ of them agreed that maximum bank operations were carried out by internet banking and one-fourth $(25.33 \%)$ of the customers narrated that all their banking transactions are carried out by them by in-person. - Majority (61.33\%) of the sampled customers in the present research have savings bank account only, $28.00 \%$ of them uses loan account and $10.67 \%$ of the customers are having the current account in the selected banks.

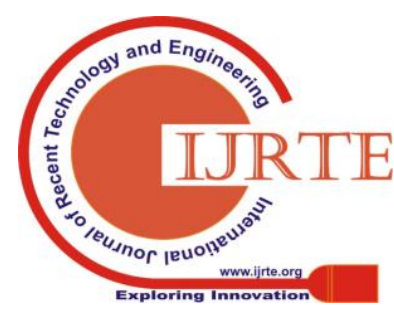




\section{Customer Experience Management (Cem) In Selected Private Banks in Chennai City}

TABLE 4. DESCRIPTIVE - MEAN AND SD

\begin{tabular}{|c|l|c|c|}
\hline $\begin{array}{l}\text { S. } \\
\text { No }\end{array}$ & Factors & Mean & SD \\
\hline 1 & Functional Clues & 21.83 & 1.367 \\
\hline 2 & Mechanic Clues & 22.13 & 1.937 \\
\hline 3 & Humanic Clues & 20.58 & 1.890 \\
\hline
\end{tabular}
Deviation of the factors used in the research. From the above analysis, it is determined that the sampled customers are satisfied with all the three clues of CEM with the mean score more than 20.0, however they have demonstrated comparatively higher level of satisfaction towards mechanic clues with the mean score of 22.13 , followed by functional clues (21.83), and humanic clues (20.58). The reason for least level of satisfaction towards humanic values are the behaviour of executives during the peak hour due to their occupational stress, which can be neutralized by employing part- time executives during peak hours to reduce the workload of permanent bank executives or offering appropriate stress management techniques / exercises to assists them to manage occupational stress in a positive manner. The SD scores of all the factors indicate that the variance among the sampled customers are in reasonable level.

\section{MULTIPLE REGRESSION ANALYSIS}

Regression analysis determines the cause and effect relationship between two or more variables. In the present research, the dependent variable is Customer Experience Management (Y), Independent variables are Functional clues (X1), Mechanic clues (X2), and Humanic Clues (X3).

Table 5. Results of Multiple Regression

\begin{tabular}{|c|l|l|}
\hline $\begin{array}{c}\text { S.N } \\
\text { o. }\end{array}$ & \multicolumn{1}{|c|}{ Particulars } & \multicolumn{1}{|c|}{ Value } \\
\hline 1 & Multiple R value & 0.846 \\
\hline 2 & R Square value & 0.734 \\
\hline 3 & Adjusted R Square & 0.728 \\
\hline 4 & F value & 92.475 \\
\hline 5 & P value & $<0.001 * *$ \\
\hline
\end{tabular}

Table 5 presents the results of multiple regression analysis between the CEM and its factors. The multiple correlation coefficient $(\mathrm{R})$ of the present model is 0.846 , which denotes the degree of relationship between the computed values and the estimated values of the Customer Experience Management (CEM). Because the estimated values are
Table 4 presents the Descriptive - Mean and Standard

obtained as a linear combination of Functional clues (X1), Mechanic clues (X2), Humanic Clues (X3), the coefficient value of 0.846 signifies the relationship between CEM and the three independent variables (i.e. dimensions of CEM) are positive. The R-square value of the current research model is 0.734 , which denotes around $73 \%$ of the variation in CEM is explicate by the estimated SRP with functional clues, mechanic clues, and humanic Clues and it is significant at $1 \%$ level.

Table 6. Variables in the multiple regression analysis

\begin{tabular}{|c|c|c|c|c|c|}
\hline Variables & $\begin{array}{l}\text { Unstandardized } \\
\text { Coefficients }\end{array}$ & $\begin{array}{l}\text { Std. } \\
\text { Error }\end{array}$ & $\begin{array}{r}\text { Standardized } \\
\text { Coefficients }\end{array}$ & $t$ value & $P$ value \\
\hline Constant & 9.468 & $\begin{array}{l}0.5 \\
63 \\
\end{array}$ & - & $\begin{array}{c}24.55 \\
7\end{array}$ & $\begin{array}{c}<0.001 \\
* *\end{array}$ \\
\hline $\begin{array}{l}\text { Functional } \\
\text { clues (X1) }\end{array}$ & 0.849 & $\begin{array}{c}0.4 \\
34 \\
\end{array}$ & 0.721 & $\begin{array}{c}11.42 \\
9\end{array}$ & $\begin{array}{c}<0.001 \\
* *\end{array}$ \\
\hline $\begin{array}{l}\text { Mechanic } \\
\text { clues (X2) }\end{array}$ & 0.793 & $\begin{array}{l}0.1 \\
46\end{array}$ & 0.864 & 9.735 & $\begin{array}{c}<0.001 \\
* *\end{array}$ \\
\hline $\begin{array}{l}\text { Humanic } \\
\text { Clues (X3) }\end{array}$ & 0.756 & $\begin{array}{l}0.0 \\
84 \\
\end{array}$ & 0.681 & 6.577 & $\begin{array}{c}<0.001 \\
* *\end{array}$ \\
\hline
\end{tabular}

Note: ** denotes $1 \%$ level of significance

Table 6 present the variables of research model with its regression coefficients. The coefficient of Functional clues is 0.721, which represents that the CEM would increase by 0.721 for every unit of increase in Functional clues. The coefficient of Mechanic clues on CEM is 0.864, which symbolize that the CEM would increase by 0.864 for every unit of increase in Mechanic clues.

The coefficient of humanic clues on CEM is 0.681which results in increase of CEM by 0.681 for every unit of increase in humanic clues and all these three coefficients are positive and significant at $1 \%$ level.

The Multiple Regression Equation is:

$$
Y=9.468+0.721 X 1+0.864 X 2+0.681 X 3
$$

As per the above table, it is understood that the standardized coefficient value, X2, i.e., "Mechanic Clues" is the most important factor that improves the Customer Experience

Management in the selected private banks followed by X1, i.e., "Functional Clues" and X3, i.e., "Humanic clues".

\section{CONCLUSION}

The customer experience management includes anything that can be perceived or sensed by the customer (Berry et al., 2002). Therefore, the private banks in order to compete with other banks by providing customers with satisfactory experience they must organise all the "clues" that people sense in the buying process. 
Private Banks must understand the customer's journey from the expectations they have before the experience occurs to the assessments, they are likely to make when it's over. Based on the results of the present research, it is concluded that the all the three clues such as functional, mechanical, and humanic clues are having significant influence on customer experience management.

\section{REFERENCES}

1. Berry, L.L. and Carbone, L.P. (2007), "Building loyalty through experience management", Quality Progress, Vol. 40 No. 9, pp. 26-32.

2. Berry, L.L., Wall, E.A. and Carbone, L.P. (2006), "Service clues and customer assessment of the service experience", Academy of Management Perspectives, Vol. 20 No. 2, pp. 43-57.

3. Berry, L.L., Carbon, L.P. and Haeckel, S.H. (2002), "Managing the total customer experience", MIT Sloan Management Review, Vol. 43 No. 3, pp. 85-89.

4. Khusnul Khotimah and Nur Choirul Afif(2016), Developing Customer Experience Model to Increase Emotional Brand, International Journal of Management and Applied Science, Volume-2, Issue-2, pp:154-158.

5. Mascarenhas, O. A., Kesavan, R., and Bernacchi, M. (2006). "Lasting customer loyalty: a total customer experience approach." Journal of Consumer Marketing 23(7): 387-405.

6. Peter C. Verhoef, Katherine N. Lemonb, A. Parasuraman c, Anne Roggeveen d, Michael Tsiros c, Leonard A. Schlesinger(2009),Customer Experience Creation: Determinants, Dynamics and Management Strategies, Journal of Retailing, Vol 85, issue 1, pp: 31-41.

7. Prashant Chauhan and Samar Sarabhai(2018), Customer Experience Management: Evolution and the Paradigm Shift in Marketing, Business Perspectives, Volume 17, Number 1, pp: 17-34.

8. Ruth N. Bolton, Janet R. McColl-Kennedy, Lilliemay Cheung, Andrew Gallan, Chiara Orsingher, Lars Witell, Mohamed Zaki, (2018) "Customer experience challenges: bringing together digital, physical and social realms", Journal of Service Management, https://doi.org/10.1108/JOSM-04-2018-0113.

9. Suvarchala, M.B. and Narasimha Rao, V. (2018), Customer experience management in banking sector- A Brief Review, International Journal of Research - Granthaalayah, Vol 6, issue 7, pp:164-178.

10. Suvarchala, M.B. and Narasimha Rao, V. (2018), An Empirical Study of Customer Experience Management In State Bank Of India And Housing Development Finance Corporation Bank, Journal of Business and Management, Volume 20, Issue 9, PP: 01-07 